\title{
A Central VQC Method based on Target Voltage Control for Local Voltage Control Devices
}

\author{
Masahiko Tanimoto Member (Mitsubishi Electric Corp., Tanimoto.Masahiko@dy.MitsubishiElectric.co.jp) \\ Hironobu MoritaＭember（Tohoku Electric Power Co., Inc., w940193@tohoku-epco.co.jp) \\ Osamu Takahashi Member (Tohoku Electric Power Co., Inc., w860333@tohoku-epco.co.jp) \\ Kunio Sakamoto Member (Tohoku Electric Power Co., Inc., w810331@tohoku-epco.co.jp) \\ Takahisa Kurokawa Member (Mitsubishi Electric Corp., Kurokawa.Takahisa@ da.MitsubishiElectric.co.jp) \\ Shinta Fukui Senior Member (Mitsubishi Electric Corp., Fukui.Shinta@dr.MitsubishiElectric.co.jp)
}

Keywords: voltage reactive power control, optimal power flow, central VQC, coordinated control

In the power grid, voltage is controlled continuously in order to keep high quality of electric power, to reduce active power transmission losses, to keep voltage stability, and to improve power system stability. High efficiency in the use of transmission infrastructure and interconnection by non-utility generators are just some of the reasons that will made voltage control an hot topic in the future.

The authors have developed a new central VQC (Voltage Q (reactive power) Control) method that cooperates with local voltage control devices AVQC (Automatic V-Q Controller) for the Tohoku EPCO transmission grid. Each AVQC, located at principal substations or power stations, brings bus voltage close to its target voltage independently from the other devices controlling on-load tap changers and shunt capacitor and reactors. While the target voltage for each bus is predetermined as a scheduled value in the

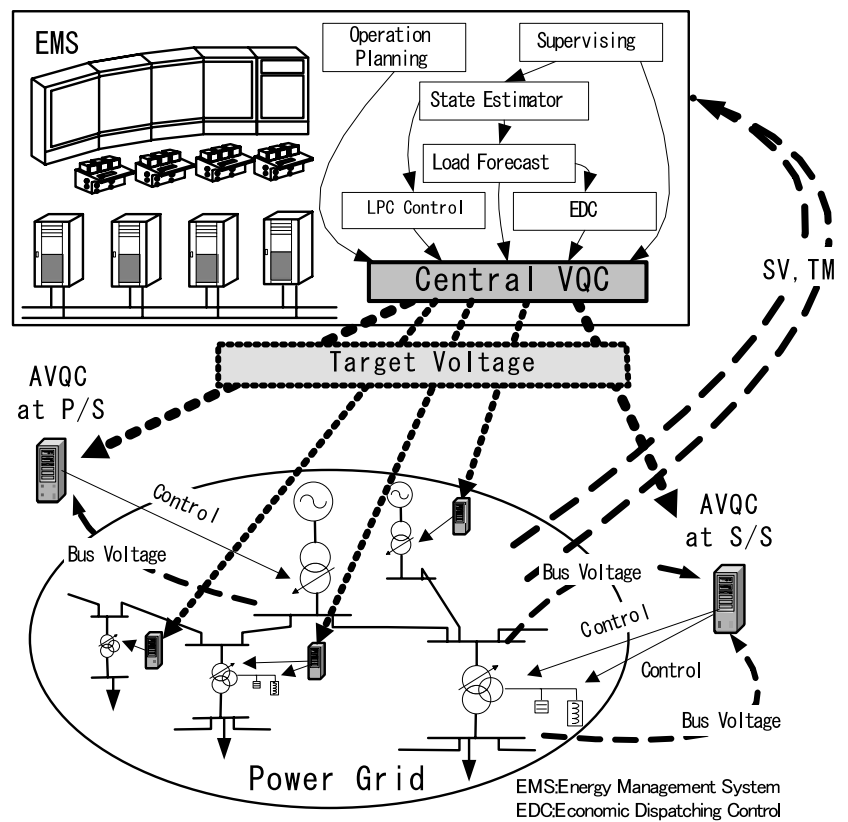

Fig. 1. An overall voltage control system using the developed central VQC method conventional VQC method, in the developed central VQC method shown in Fig. 1, the target voltage is determined through on-line optimal power flow (OPF) calculation in order to minimize active power transmission losses in the bulk power grid. Efficient voltage control is realized in comparison with the conventional VQC, since the target voltage is optimally updated every few minutes in accordance with the current power grid state.

The central VQC function is operated in conjunction with several functionalities in the energy management system (EMS) at Tohoku EPCO also shown in Fig. 1. Both a state estimator and a reliable and high-speed OPF calculator are indispensable in order to control voltage using this central VQC method. The state estimator outputs the best estimation of the power grid state variables from redundent measurements and network topology data every few minutes. The OPF calculator determines the target voltage for each local device in the current power grid state, such state is calculated based on the estimated data with several functions, such as "economic dispatching control" and "load forecasting".

This paper presents the newly developed method for a central VQC scheme, the implementation of the method as one of the functions of the EMS at Tohoku EPCO, and its effectiveness verified through bus voltages behaviors of the real Tohoku EPCO power grid state (Fig. 2). On the basis of the results, the voltage control function, employing the developed central VQC method, has been in operation from 2004.

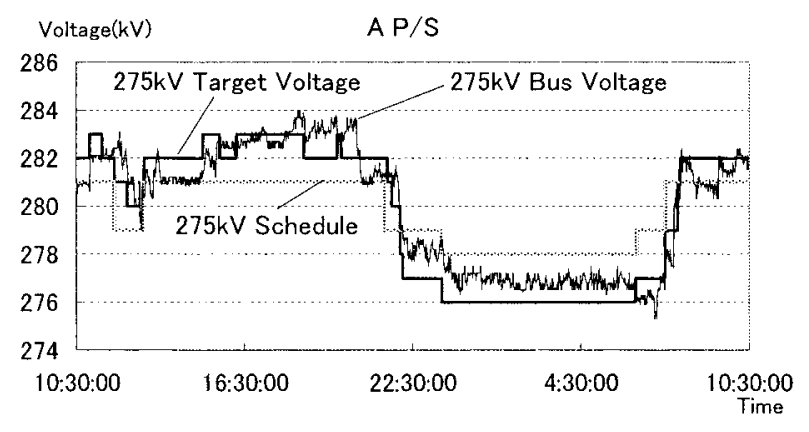

Fig. 2. Transition of bus voltage and target voltage 


\title{
個別 VQC 装置への目標電圧指令による中央 VQC 方式
}

\begin{tabular}{|c|c|c|c|}
\hline 員 谷本 & 昌彦* & 正 & 森田 \\
\hline 正 員 高橋 & 修** & 正 & 坂本 \\
\hline 是 & 隆久 久** & 上級会員 & \\
\hline
\end{tabular}

A Central VQC Method based on Target Voltage Control for Local Voltage Control Devices

\author{
Masahiko Tanimoto*, Member, Hironobu Morita**, Member, Osamu Takahashi**, Member, \\ Kunio Sakamoto** $^{* *}$ Member, Takahisa Kurokawa***, Member, Shinta Fukui***, Senior Member
}

\begin{abstract}
The authors have developed a new central VQC (Voltage Q(reactive power) Control) method that cooperates with local voltage control devices AVQC (Automatic V-Q Controller). Each AVQC, located at principal substations or power stations, brings bus voltage close to its target voltage independently by controlling the on-load tap changers and shunt capacitors and reactors status. Each target bus voltage is optimally determined through on-line optimal power flow calculation to minimize active power transmission losses in the bulk power grid. Using this central VQC method, efficient voltage control is realized in comparison with the conventional VQC since the target voltage is updated continuously in accordance with the current power grid state. The voltage control function employing the described method has been already implemented into the energy management system at Tohoku EPCO and has been in operation from 2004.

This paper presents the newly developed method for central VQC and its excellent performance through bus voltages behaviors at the real Tohoku EPCO power grid.
\end{abstract}

キーワード : 電圧無効電力制御, 最適潮流計算, 中央 VQC, 協調制御

Keywords: voltage reactive power control, optimal power flow, central vqc, coordinated control

\section{1. はじめに}

電力系統の運用において, 需要家電圧や系統電圧の適正 範囲維持による電力の品質向上，送電損失の軽減，電圧安 定性の維持，安定度の向上などを目的として電圧の調整が 行われている。今後，送変電設備のさらなる効率的な運用 が求められていることに加え，パワエレ機器などの定電力 負荷の増加, さらには, 多様な電気事業者の電力系統への 接続などにより，電圧の制御はこれまでにも増して重要に なっている。

* 三菱電機（株） 先端技術総合研究所

Advanced Technology R\&D Center, Mitsubishi Electric Corp.

8-1-1, Tsukaguchi-Honmachi, Amagasaki 661-8661

** 東北電力 (株)

干980-8550 仙台市青葉区本町 1 丁目 7 番 1 号

Tohoku Electric Power Co., Inc.

7-1, Honcho, 1-chome, Aoba-ku, Sendai 980-8550

*** 三菱電機（株） 系統変電システム製作所

₹ 100-8310＼cjkstart東京都千代田区丸の内 2-7-3

Transmission \& Distribution Systems Center, Mitsubishi Electric Corp.

2-7-3, Marunouchi, Chiyoda-ku, Tokyo 100-8310
これまでに基幹系統の電圧無効電力制御（VQC；Voltage Q (reactive power) Control) を行うために, 種々の方式が 提案されているが(1)(2), これらは

（1）変電所や発電所に設置されたローカル電圧制御装 置 (以下, AVQC (Automatic V-Q Controller) 装置) により局所情報を用いて制御を行う個別 VQC 方式

（2）中央給電指令所（以下，中給）などにおいて系統 全体にわたる最適化計算を行い，その結果に基づき 制御を行う中央 VQC 方式

に大別することができる。東北電力ではこれまで個別 VQC 方式による電圧制御を行ってきたが, さらなる効率的な電 圧制御を行うために, 既設の AVQC 装置を活かした中央 VQC 方式を開発した。本中央 VQC 方式では, 送電損失の 低減を図るため, 中給において最適な系統状態を計算し, 中 給から AVQC 装置に対して目標電圧指令を行う。この中給 から指令された目標電圧に応じて, AVQC 装置が自電気所 の電圧を, 変圧器タップのタップ位置 (以下, タップ) や 調相設備（SC：Shunt Capacitor/SR：Shunt Reactor）の投 入/開放状態を切り替えて制御することで, 系統全体の電圧 を安定に制御することができる。

本中央 VQC 方式は東北電力中給システムの電圧制御機 
能に実装されており，シミュレーションによりその効果を 確認してきたが(3)(4)，さらに実運用に向けて連動試験を実施 した。本稿では，開発した方式およびそのシステム構成に ついて紹介するとともに，連動試験の結果として本方式に より，系統電圧が適正に制御できていることを示す

なお，本方式を用いた電圧制御機能は，2004 年 12 月よ り実運用を開始している。

\section{2. 従来の VQC 方式}

$\langle\mathbf{2} \cdot \mathbf{1}\rangle$ 個別 VQC 方式 個別 VQC 方式は，主な変電 所・発電所に設置された AVQC 装置により，個別に電圧を 目標值近傍に制御することで系統全体の電圧を制御する方 式である。あらかじめ, 系統運用計画などを基にAVQC 装 置ごとに目標電圧スケジュールを定めておき，これに対して 電圧や無効電力潮流などの自電気所で計測した情報と比較 し，タップ切替や調相設備の投入/開放の制御を行う（図 1)。

AVQC 装置による制御は,

・取り扱うデータが局所情報のみであり，演算量が少な いため，負荷急変時などにも，すばやい動作が可能

・あらかじめスケジュールとして設定された目標電圧值 に近づくように制御するため，実際の系統と想定系統 との状態の違いにより，全体として必ずしも効率的に ならない場合がある

などの特徴がある。

$\langle\mathbf{2} \cdot \mathbf{2}\rangle$ 中央 VQC 方式 中央 VQC 方式は，制御装置 に対して, 中給などで計算した最適潮流計算 (OPF：Optimal Power Flow）の結果に基づく指令を行うことで，系統全体 の電圧を総合的に制御するものである。OPF 計算で最適化 を行う問題は，一般に次のように書ける。

$$
\left.\begin{array}{lll}
\min & f(x) \\
\text { subject to } & g_{i}(x) \leq 0 & (i=0, \cdots, m) \\
& h_{j}(x)=0 & (j=0, \cdots, n)
\end{array}\right\}
$$

ただし，

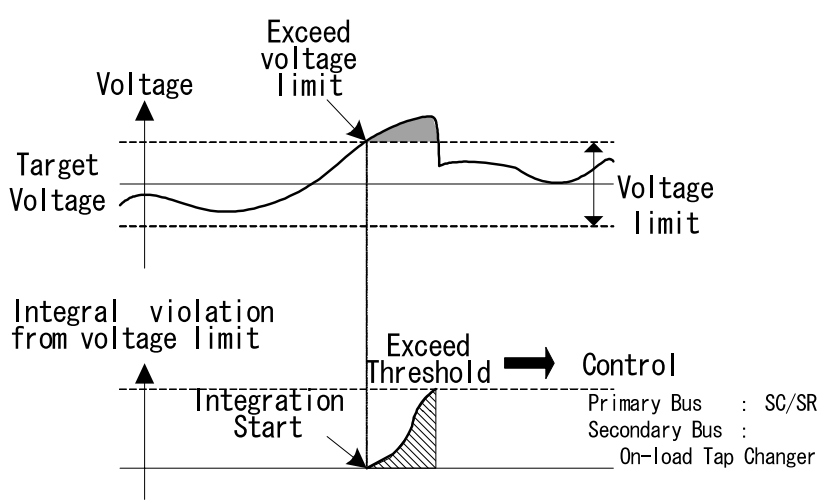

図 1 AVQC 装置の制御動作原理

Fig. 1. A voltage control principle of local voltage control device (AVQC). $f(x)$ : 評価関数（送電損失，基準電圧偏差など）

$g(x)$ : 不等式制約条件

·母線電圧上下限制約

·発電機無効電力出力上下限制約

·連系線無効電力潮流上下限制約

$h(x)$ : 等式制約条件

- 潮流方程式

ここで, 制御変数 $x$ は変圧器タップ位置, 調相設備の投入/ 開放状態であり，これらは離散值であるため，この問題は 組み合わせ最適化問題となる。また, 電圧問題であること から OPF 計算は，交流法に基づくことになる。この OPF を解く場合, 求解の安定化のために逐次線形化し線形計画 法を用いて制御出力を計算することが多い ${ }^{(1)}$ 。

また，ここで，計算により得られた最適な系統状態を直 接制御によりそのまま実現する場合には，

・デー夕の処理量が多く, OPF 計算に時間がかかるため に，秒オーダーでの制御は難しい,

・負荷急変時などに制御遅れが発生しやすい,

-系統状態の変化に対して, OPF 計算による最適系統の 電圧分布自体は大きく変わらないが，それを実現する 機器状態が異なる場合がある。このため, 頻繁な機器 動作が発生し, 結果的に系統電圧の変動が生じる可能 性がある，

といった課題がある。

中央 VQC 方式による電圧制御を実現するためには，(1) 収集したテレメータ值から系統状態を同定する状態推定計 算，（2）高速かつ安定に最適解を得る OPF 計算エンジン, （3）中給と動作する装置間の情報伝送路の整備, が条件と なる。特に, 上述のように式 1 の最適化問題は交流法に基 づく OPF 計算となることから，これをオンラインで実施す るためには, 状態推定計算によってその時点の系統状態を 高い精度で得る必要がある。

\section{3. 開発した中央 VQC 方式}

〈3・1〉 AVQC 装置との協調 東北電力の中給システ ムでは, 状態推定計算機能が実装されており (5), これまで の検証において，その精度が十分高いことを確認している。 また高速・安定に最適解を求める OPF 計算機能 (6) も実装さ れており, 中央 VQC 方式による電圧制御実現のための条件 が整備されたしかしながら，タップや調相設備を中央から 直接的に制御する方法では，前章で述べた課題を解決する ことは難しい。一方, 東北電力では，これまで個別 VQC 方 式を採用してきたことから, 主要な超高圧変電所および発 電所には，前章で述べた AVQC 装置や PSVR（Power System Voltage Regulator) 装置がすでに設置されている（以 下, PSVR 装置についてもAVQC 装置に含めて考えること とする)。

そこで，今回開発した中央 VQC 方式は，これらの既設 装置を活用し，系統全体の効率的な制御を実現する。具体 
的には，本方式では OPF 計算結果に基づくタップや調相設 備への直接的な制御ではなく, AVQC 装置への目標電圧指 令を行うことで，次のように系統全体を階層的に制御する。

（1）中給における OPF 計算によって，需給変動に対応 した最適な系統状態を求め, このときの電圧值（最適電圧 分布）を AVQC 装置の目標電圧として指令する。

（2）タップや調相設備への制御出力は, 中給から指令 された目標電圧に従い, 従来通り, AVQC 装置が行う。

これにより, 各電気所の電圧を, 中給において OPF 計算 で得られた系統全体にとって最適な值に近づけることがで きる。また，各電気所において目標電圧からの急激な電圧 変動があった場合にも，個別にAVQC 装置が制御すること による迅速な対応が可能であり，中給で集中管理した場合 に生じやすい制御遅れを避けることができる。

〈3.2〉計算周期と先行制御 前節で述べたように, 本 中央 VQC 方式では, 各母線電圧の変動については AVQC 装置が制御するため，時々刻々の状態变更に対応する必要 はない。すなわち, 中給の主な役割は 1 日の大きな流れの 中で生じる系統の緩やかな変化や突発的に生じる大きな変 化に対応して，目標電圧指令を通して系統全体の最適な電 圧分布を与えることである。そこで本中央 VQC 方式によ る電圧制御機能の設計においては, 目標電圧の計算・指令 周期を 9 分間隔に設定した。

また，既設の AVQC 装置は，図 1 に示したように目標電 圧からの偏差（厳密には不感帯からの逸脱量）の積分量を 計算して機器に対して制御出力を送る。よって，たとえ目 標電圧を変更しても，電圧がその目標電圧近傍に制御され るまでには時間遅れが生じる。例えば，昼のような負荷急 変時において所望の目標電圧近傍に系統電圧を制御するに は，この時間遅れを考慮してあらかじめ目標電圧を先行的 に設定しておく必要がある（現状の AVQC 装置に設定され たスケジュール值でも 10 分程度の時間遅れが考慮されて いる）。そこで，本中央 VQC 方式では，OPF 計算を 1 時 点先，すなわち 9 分先の予測系統に対して行い，これに基 づく指令を行う。これにより，計算から 9 分後の仕上がり の電圧分布が最適な分布に近づくことが期待できる。なお， 万一の系統事故などにより大きな電圧違反が検出された場 合は，9分先ではなく，当該時点の系統断面に対して OPF 計算を行い, AVQC 装置への臨時目標電圧指令を行う機能 を有している(目標電圧臨時指令機能)。

なお，本中央 VQC 方式では，予測系統に対する制御を 実施することや，OPF 計算結果のタップや調相設備の状態 をそのまま実現するものではないことから，9分先の仕上 がりの系統状態がまさに最適な状態になっているとは限ら ない。しかし，最適な目標電圧分布自体は系統状態の変化 に対しても比較的安定しているため（負荷状態が変わって も電圧の制御目標が大きく変動するわけではない), AVQC 装置により系統電圧に大きな衝撃を与えることなく, 最適 な電圧分布近傍へ連続的に制御を行うことができる。

$\langle\mathbf{3 \cdot 3 \rangle}$ 最適目標電圧計算本節では, 9 分先予測系統
における最適な系統状態を求める OPF 計算について述べ る。OPF 計算の目的関数を (2) 式に示す。

$$
\begin{aligned}
& \min f(x)=w_{1} P_{\mathrm{L}}(x)+w_{2} \sum\left(v_{i}-\overline{v_{i}}\right)^{2} \cdots \cdots \cdots(2) \\
& v_{i}, \overline{v_{i}}: \text { 中給制御対象外 AVQC 装置の制御対象母線 } \\
& \text { 電圧および目標電圧 (スケジュール值) } \\
& w_{1}, w_{2} \text { : 重み係数 }
\end{aligned}
$$

ここで, 変数 $x$ は系統内の電圧制御機器の状態, すなわち AVQC 装置により制御される変圧器タップの位置および調 相設備の入切状態, PSVRの発電機端子電圧である。よっ て，この問題は組み合わせ最適化問題となるが，本 OPFで は, まず, 変数 $x$ のうち, 離散值である変圧器夕ップの位 置および調相設備の入切状態を, 連続值の変圧器夕ップ比 および調相の投入量とし，これらの変数に対する感度行列 を用いた 2 次計画問題を解く。次にこの解を初期解として 離散化し, 組み合わせ最適化問題として問題空間探索法に 基づく近傍探索を行い，最適解を求める ${ }^{(6)}$ 。なお，予測系 統における有効電力に関する变数 (発電機有効電力出力や 位相変圧器夕ップ位置) は, 中給の他の機能（需給制御機 能や位相変圧器制御機能）において決定された值を引き継 いでおり，本 OPF 計算の中では固定值として扱う。

(2) 式で示した目的関数の第 1 項 $P_{L}(x)$ は系統全体の送電 損失であり，これを低減することが本中央 VQC 方式による 電圧制御の主たる目的である。第 2 項は, 中給からの制御 対象外 AVQC 装置による制御の影響を考慮するための項で ある。中給の制御対象でない AVQC 装置では, 従来通り, スケジュール值として与えられた目標電圧に基づく個別制 御を行うために，これらの AVQC 装置により制御される母 線の電圧はスケジュール值近傍となる。(2) 式の第 2 項を 目的関数として加えることで, 計算結果として得られる最 適系統の電圧值を当該スケジュール電圧近傍とし, 実際の 仕上がり電圧と最適系統の電圧分布の違いを小さくし, 最 適系統の実現性を高めている。なお，重み係数 $w_{1}, w_{2}$ は， 送電損失の低減効果と AVQC 装置制御対象母線電圧の電圧 変化のバランスを勘案して試験を通じて決定した。

$\mathrm{OPF}$ 計算に与える制約条件は，等式制約として潮流方程 式，また，不等式制約として，系統監視機能で設定された （1）母線電圧監視值の上下限制約，（2）発電機の無効電力 出力上下限制約, (3) 連系線無効電力潮流の上下限制約, に加え，（4）運用者設定による目標電圧の指令範囲制約, を電圧の上下限制約として与え, 指令值が運用者の設定值 以上に変化しないようにした。なお，系統状態によっては これらの制約条件を課した場合に，実行可能解がなくなる 場合が生じるが，この場合は電圧の上下限制約を緩和して 計算を進める。

〈3・4〉 全体システム構成 本中央 VQC 方式による電 圧制御機能は, 中給システムの他の機能と密に連係して動 作する ${ }^{(7)}$ 。関連する主な機能について以下に示す（図 2)。

(1) 系統監視機能 電圧, 発電機無効電力, 潮流等 のテレメータを監視する数值監視, $\mathrm{CB}$ 状変等の $\mathrm{SV}$ 情報 


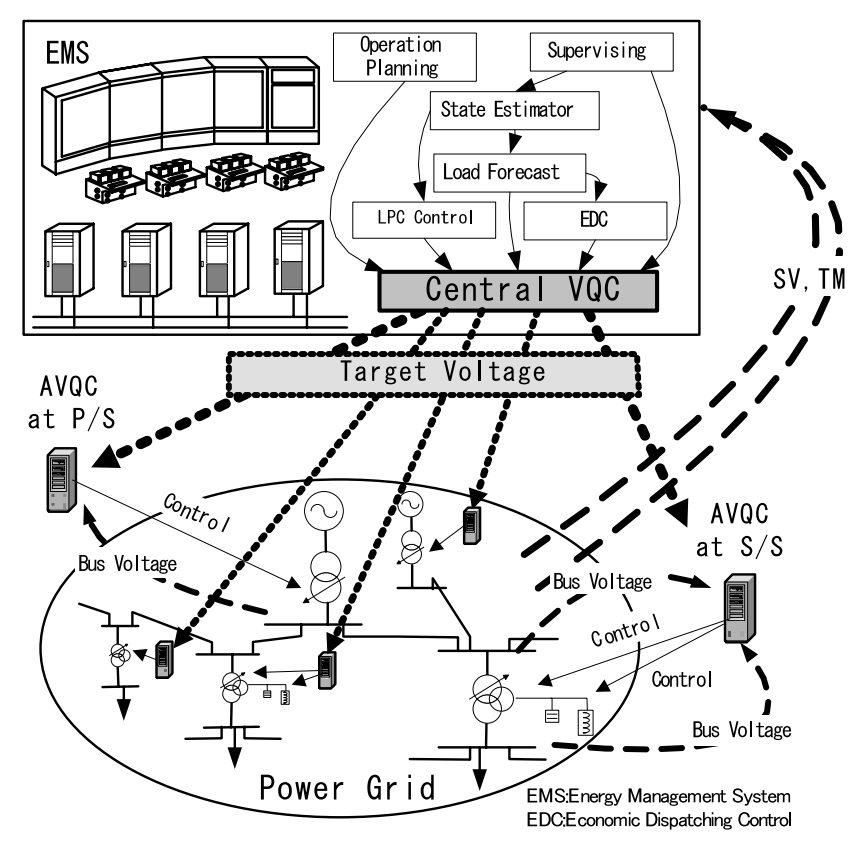

図 2 中央 VQC 方式による電圧制御全体図

Fig. 2. An overall voltage control system using the developed central VQC method.

を監視する 2 值監視, 伝送系の監視等を行う電圧制御機能 では，目標電圧指令によって監視值違反が発生しないよう に, 本機能で設定された監視值を OPF 計算の制約条件とし て設定する。

（2）状態推定機能，母線負荷予測機能 現在断面の 状態推定計算を行うとともに，この状態推定計算結果を用 いて, 将来断面の母線負荷予測を行う母線負荷予測機能は, 現在時点の状態推定結果と, 蓄積した過去の状態推定結果 の統計データを用いて将来の各母線の負荷值を予測する。 電圧制御機能では 9 分先予測系統の母線負荷值として本機 能の計算結果を設定する。

(3) 需給制御機能 ${ }^{(8)}$ 発電コストを低減するように 発電機の出力指令を行う。特に, 本中給の EDC 機能は将来 の需要予測に応じた多断面の経済負荷配分計算を行い, 発 電機の指令值を計算する。電圧制御機能では 9 分先予測系 統の発電機想定出力として本機能の計算結果を設定する。

（4）位相変圧器制御機能送電損失低減を目的とし て, 位相調整器および位相調整変圧器のタップ位置を OPF 計算により計算し，これに基づき制御する。電圧制御機能 では 9 分先予測系統の位相変圧器タップ位置として本機能 の計算結果を設定する。

（5）系統運用計画機能年間，月間，週間，翌日の 将来時点の系統運用計画を立案する電圧制御機能では, 翌 日系統運用計画機能により求められた各 AVQC 装置の目標 電圧デー夕を引き継ぐことが可能となっており，立案され た計画に基づいた計算・制御を実行することができる。

$\langle\mathbf{3 . 5}\rangle$ 中給システム電圧制御機能概要 中給システ ムの電圧制御機能はこれまで述べた OPF 計算に基づく目標 電圧指令機能の他に, 以下の機能を持つ。
（1）運用者による目標電圧指令機能 中給から制御 可能状態となっている AVQC 装置に対して目標電圧を指令 する AVQC 装置ごとに, OPF 計算結果に基づく目標電圧 の他, 系統運用計画にて立案したスケジュール值, AVQC 装置ローカルに設定されたスケジュール值，中給運用者の 指定值を運用者の設定切り替えにより，指令できる。

（2）各制御対象母線の電圧值および目標電圧表示機能 AVQC 装置のスイッチ状態の表示, AVQC 装置制御対象母 線の現在電圧および目標電圧の表示, 監視を行う電圧違反 発生時は系統監視機能と連動し, 画面上に違反レベルに応 じた表示を行い, 運用者に通知する。

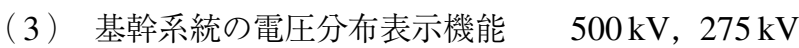
系統の電圧の現在值, OPF 計算結果による電圧の分布をグ ラフ表示する。

（4） AVQC 装置の諸定数デー夕管理機能 AVQC 装 置に設定されたスケジュールや不感帯, 積分時間等のパラ メータを設定・管理する。

（5）制御装置動作記録機能各発・変電所のタップ および調相設備の入切の動作回数を記録する。

（6）目標電圧臨時指令機能系統監視機能により, 大 きな電圧違反が検出された場合, 9 分間隔の制御夕イミン グに拘らず, OPF 計算を行い, 擾乱後の状態に対する目標 電圧指令を行い，系統の安定化を図る。

\section{4. 実系統による連動試験検証}

本中央 VQC 方式における，系統状態に応じた目標電圧 指令や送電損失の低減効果といった有効性については，す でに OPF 計算により得られる電圧分布の検証，および，訓 練シミュレータを用いた検証を通して確認してきた ${ }^{(3)(4)}$ 。そ こで, 本中央 VQC 方式による電圧制御が正しく行われ，実 際に運用可能であることを確認するために，2004 年 9 月 に， 1 週間にわたって実際の東北電力系統に対して本方式 により制御する，連動試験運転を行った。

実施した試験条件として, 東北電力の $275 \mathrm{kV}$ 系統の発・ 変電所のうち, 他社系統との連系個所を除き, すでに中給と の情報伝送路の整備が完了した 13 箇所の AVQC 設備（内， 発電所に設置されているもの 4 設備）を中給からの制御対 象とし, 他の AVQC 設備および PSVR 設備については, ス ケジュール值に基づく個別制御とした。

また, 目標電圧指令条件として, 従来の制御で用いてい たスケジュール電圧を指令值の基準とし，この指令基準值 から $1 \mathrm{kV}$ もくは $2 \mathrm{kV}$ の範囲内となるように設定した。 図 3 に指令範囲を $1 \mathrm{kV}$ とした場合の平日 1 日間の $275 \mathrm{kV}$ 発・変電所の電圧指令值および母線電圧值の推移例を示す。 同様に，翌日（平日）に指令範囲を $2 \mathrm{kV}$ に変更した場合の 結果を図 4 に示す。また, 図 5 および図 6 にそれぞれの場 合のタップ, 調相設備の制御動作履歴を示す。

この結果，昼間帯においては，送電損失低減のため，元 のスケジュール值より高い目標電圧值を指令送出するとと もに，系統電圧が当該指令值に近づくように推移している 


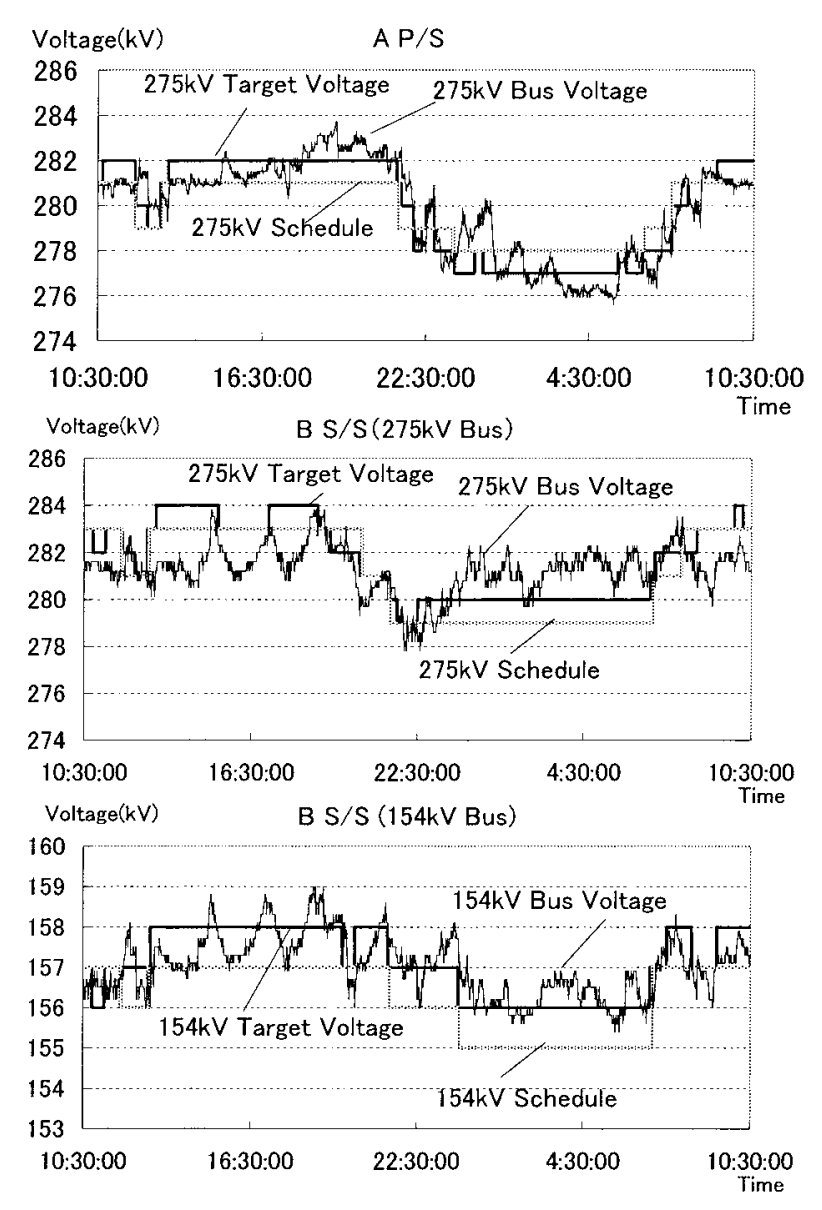

図 3 制御対象母線電圧推移

(指令範囲：スケジュール值 $\pm 1 \mathrm{kV}$ )

Fig. 3. Transition of bus voltage

(Target voltage range: schedule $\pm 1 \mathrm{kV}$ ).

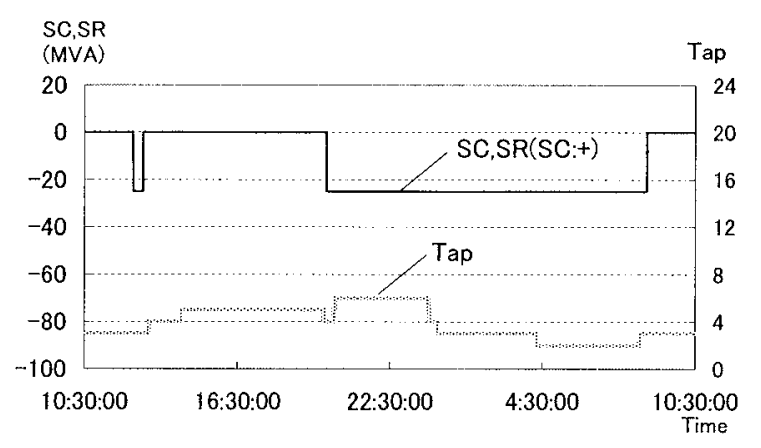

図 5 調相設備, タップ動作推移 (B S/S)

（指令範囲：スケジュール值 $\pm 1 \mathrm{kV}$ )

Fig. 5. Transition of SC, SR and Tap at B S/S

(Target voltage range: schedule $\pm 1 \mathrm{kV}$ ).

ことが分かる。また，夜間帯においては，負荷が軽いこと による電圧上昇傾向に対して，A P/S で制御対象母線電圧 を低めにすることで, 系統全体の電圧を抑える方向に制御 しているとともに，B S/S の $154 \mathrm{kV}$ 母線においても，電圧 を目標值近傍に制御できていることが分かる。

また，指令範囲を $1 \mathrm{kV}$ とした場合に比べ， $2 \mathrm{kV}$ とした 場合の方が, 制御できる範囲が広いことから, 当然ながら

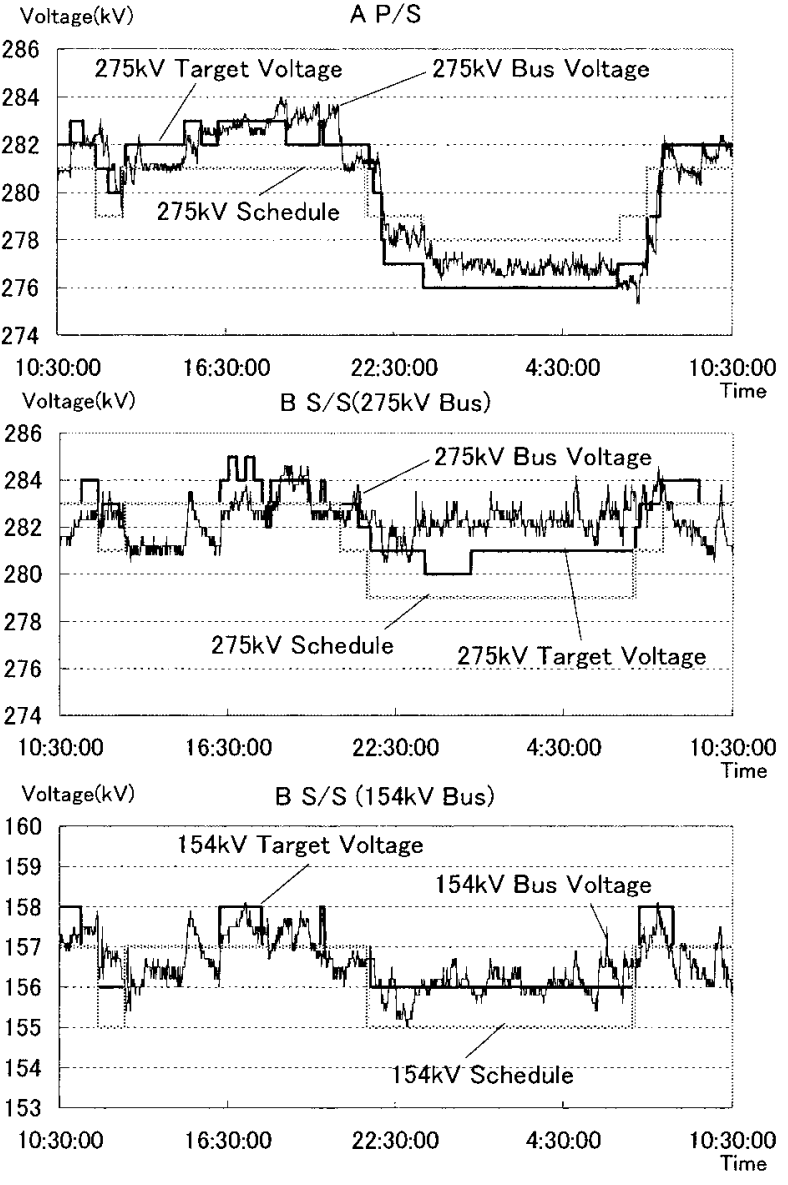

図 4 制御対象母線電圧推移

(指令範囲：スケジュール值 $\pm 2 \mathrm{kV}$ )

Fig. 4. Transition of bus voltage

(Target voltage range: schedule $\pm 2 \mathrm{kV}$ ).

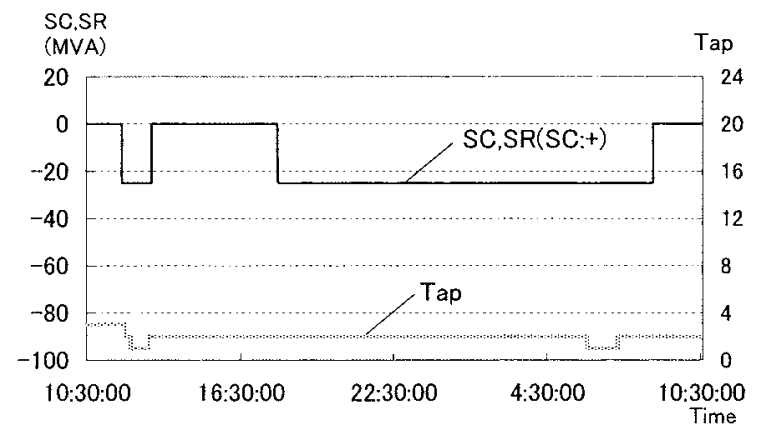

図 6 調相設備, タップ動作推移 (B S/S )

(指令範囲：スケジュール值 $\pm 2 \mathrm{kV}$ )

Fig. 6. Transition of SC, SR and Tap at B S/S (Target voltage range: schedule $\pm 2 \mathrm{kV}$ ).

目標電圧の変更回数が多くなる傾向となるが， $2 \mathrm{kV}$ 設定の 範囲では, 制御機器の動作回数には大きな影響を及ぼして いない。このパラメータをどの程度まで広げることが運用 上妥当かについては, 今後の運用に基づいて決定されてい くものと考える。

なお，本期間を通じて，OPF 計算の制御対象母線である かどうかにかかわらず, 系統運用者による監視対象母線に 
対する電圧違反や系統擾乱は発生しなかった。

\section{5. あとがき}

既設 AVQC 装置を活用し，AVQC 装置に対して OPF 計 算で得られる目標電圧を指令することで，系統全体の電圧 を安定に制御しつつ，送電損失低減を図る新しい中央 VQC 方式について述べたまた，実系統に対して連動試験を実施 し，その結果，本方式によって系統全体の電圧を安定に制 御できることを確認した。

本方式による電圧制御機能は東北電力の中給システムに 実装されて抢り，本検証結果に基づき，最終調整の後に， 2004 年 12 月より実運用に入っている。今後も, 既設 AVQC 装置と中給間の情報伝送路を整備し，本方式による制御対 象を順次増やしていく予定である。

(平成 17 年 7 月 28 日受付，平成 18 年 2 月 6 日再受付)

\section{文献}

（1）「電力系統の電圧 ·無効電力制御」, 電気学会技術報告, No.743 (1999)

(2) M. Tanimoto, Y. Izui, K. Iba, N. Fukuta, K. Deno, and T. Sasaki: "An Autonomous Distributed VQC Method based on Q-TBC", T. IEE Japan, Vol.120-B, No.6, pp.815-822 (2000-6) (in Japanese) 谷本昌彦 - 泉井良夫 · 伊庭健二 福田尚人 · 出野賢一 佐々木鉄於 : 「Q-TBC (Q Tie-Line Bias Control）方式による自律分散型電圧・無効 電力制御」, 電学論 B, 120, 6, pp.815-822 (2000-6)

(3) M. Tamura, O. Takahashi, E. Tsukada, M. Tanimoto, and J. Ohtani: "Development on a Central VQC Method based upon Setting Target Voltage for Local Control Equipment", 2003 National Convention Record IEE Japan, No.6-104, pp.175-176 (2003-3) (in Japanese)

田村光成・高橋 修. 塚田英一・谷本昌彦・大谷純一: 「目標電圧指 令に基づく階層型中央 VQC 方式の開発」, 平成 15 年電気学会全国 大会, No.6-104, pp.175-176 (2003-3)

(4) M. Tanimoto, M. Matsumoto, O. Takahashi, E. Tsukada, and J. Ohtani: "Applying a Central VQC Method based upon Setting Target Voltage for Local Voltage Control Device", The Papers of Joint Technical Meeting on PE and PSE, IEE Japan, PE-03-121/PSE-03-132 (2003) (in Japanese)

谷本昌彦・松本光裕・高橋 修・塚田英一・大谷純一：「目標電圧指 令に基づく階層型中央 VQC 方式の適用」, 電気学会電力技術 ·電力 系統技術合同研資, PE-03-121/PSE-03-132 (2003)

( 5 ) O. Takahashi, T. Ishihara, O. Ishioka, M. Usui, S. Fujiwara, and T. Kurokawa: "Online Security Moniterring for the next Energy Management System of Tohoku EPCO", The Papers of Technical Meeting on PSE IEE Japan, PSE-02-5 (2002) (in Japanese)

高橋 修 - 石原 徹 - 石岡 修 - 白井正洋 - 藤原修平 - 黑川隆久： 「次期中央給電指令所システムにおけるオンライン信頼度監視機能 について」, 電気学会電力系統技術研資, PSE-02-5 (2002)

(6) M. Tamura, O. Takahashi, T. Ishihara, N. Itaya, and S. Nakamura: "Development of Fast Optimal Load Flow Algorithm", The Papers of Joint Technical Meeting on PE and PSE, IEE Japan, PE-02-135/PSE-02-145 (2002) (in Japanese)

田村光成・高橋 修·石原 徹 - 板屋伸彦・中村静香：「高速最適潮 流計算アルゴリズムの開発」, 電気学会電力技術・電力系統技術合同 研資, PE-02-135/PSE-02-145 (2002)

( 7 ) O. Takahashi, T. Ishihara, O. Ishioka, S. Itou, T. Kurokawa, J. Ohtani, and K. Dan: "The Next Energy Management System of Tohoku EPCO", Proc. of the $12^{\text {th }}$ Annual Conference of Power \& Energy Society, IEE Japan, Vol.A, pp.580-581 (2000-8) (in Japanese)

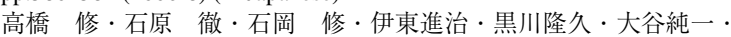
団幸太郎:「次期中央給電指令所システムの概要」, 平成 13 年電気学 会 B 部門大会, A 分冊, pp.580-581 (2000-8)

(8) Y. Kojima, S. Nakamura, K. Abe, O. Takahashi, E. Tsukada, and T. Kurokawa: "Development of EDC Considering Cooperation with AFC", IEEJ Trans. PE, Vol.125, No.2, pp.170-176 (2005-2) (in Japanese) 小島康弘 · 中村静香 · 阿部公哉 ·高橋 修·塚田英一 - 黒川隆久 : 「AFC との協調制御を考慮した EDC の実用化」, 電学論 B, 125, 2, pp.170-176 (2005-2)

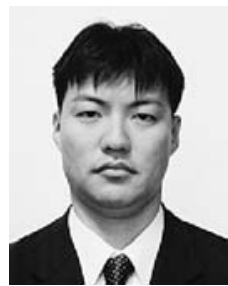

（正員） 1969 年 11 月 12 日生。1994 年 3 月京 都大学大学院工学研究科電気工学専攻修士課程終 了。同年 4 月三菱電機（株）入社。先端技術総合 研究所にて, 主として電力系統の制御・最適化, 電 力自由化システムの設計などに従事。IEEE 会員。
森 田 博 信

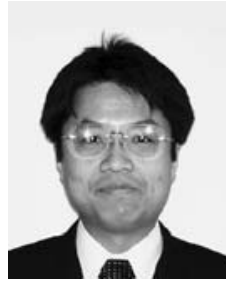

高 橋

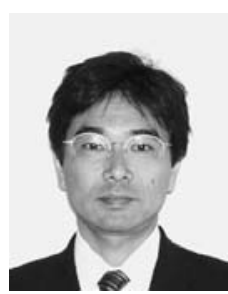

坂 本 邦 夫

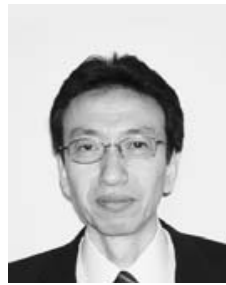

黒川隆久

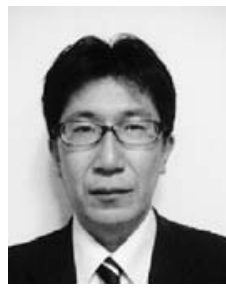

福 井伸 太

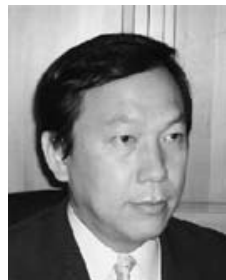

（正員） 1968 年 8 月 8 日生。1994 年 3 月早稲田 大学大学院理工学研究科電気工学専攻修士課程修 了。同年 4 月東北電力（株）入社。主として電力 系統の制御・解析に関する業務に従事。
（正員） 1958 年 3 月 30 日生。1981 年 3 月東北 大学工学部電子工学科卒業。同年 4 月東北電力 （株）入社。主として電力系統の計画に関する業 務に従事。 田大学理工学部電気工学科卒業。同年 4 月東北電 力 (株) 入社。主として電力系統制御システムの 開発に関する業務に従事。 